\title{
Analisis Performansi LMS SYAM OK dalam Pembelajaran di UNM
}

\author{
Veronika Asri Tandirerung \\ Pendidikan Teknik Elektro,Universitas Negeri Makassar \\ veronika.asri@unm.ac.id
}

\begin{abstract}
Abstrak - Pembelajaran yang diterapkan dalam rangka memutus mata rantai penyebaran virus covid-19 adalah pembelajaran dalam jaringan (Daring). Pembelajaran ini memerlukan internet sebagai sumber utama pembelajaran dan berbagai platform digital pembelajaran yang open source sehingga dapat digunakan oleh semua satuan Pendidikan. Berbagai platform tersebut memiliki kelebihan dan kelemahan masing-masing. Pembelajaran di Perguruan Tinggi yang selama ini terlaksana secara tatap muka dan diintegrasikan dengan Teknologi Informasi dan Komunikasi (TIK) tentunya tidak mengalami banyak kesulitan dalam melaksanakan pembelajaran daring. Akan tetapi belum seragamnya platform pembelajaran yang digunakan dosen sehingga perlu adanya Learnng Management System yang terpadu dan terintegrasi sehingga proses pembelajaran dapat dimonitoring dan dapat dilakukan evaluasi demi terjaminnya mutu dan kualitas pembelajaran di masa pandemi. Universitas Negeri Makassar sebagai salah satu perguruan tinggi jauh sebelum masa pandemic sudah memiliki LMS untuk pembelajaran berbasis e-learning, akan tetapi penggunaannya belum dimaksimalkan karena masih banyak dosen yang menggunakan platform e-learning yang lain. Di masa pandemic, UNM memusatkan pelaksanaan pembelajaran melalui LMS SYAM OK. Dengan kebijakan ini, perlu dilakukan analisis performansi terhadap website LMS sehingga dapat memberikan masukan dan menjadi bahan evaluasi dalam peningkatan maupun pengembangan LMS ke depannya. Pengujian yang dilakukan meliputi pengujian performansi, kecepatan, load dan stress. Pengujian dilakukan melalui Pingdom tools, GTMetrix, webpage test dan Load storm. Hasil pengujian performansi dengan Pingdom tools yakni LMS SYAM OK berada pada grade C artinya cukup Baik sedangkan menurut GTMetrix berada pada kategori $\mathrm{F}$ artinya kurang baik. Hasil pengujian load testing menunjukkan hasil cukup baik dan hasil pengujian stress menunjukkan nilai cukup tinggi.
\end{abstract}

Keywords— LMS SYAM OK, Pingdom tools, GTMetrix, Performansi, load testing, Stress Testing.

\section{Pendahuluan}

Penyebaran virus covid-19 mengubah paradigma pembelajaran yang selama ini dilaksanakan secara tatap muka dan blended learning menjadi pembelajaran yang sepenuhnya dilaksanakan dalam jaringan (full daring). Surat Edaran (SE) Mendikbud Nomor 4 tahun 2020 (Kemendikbud, 2020a) tentang "pelaksanaan kebijakan pendidikan dalam masa darurat penyebaran coronavirus disease", ditetapkan bahwa proses pembelajaran di semua jenjang pendidikan dilaksanakan secara daring/online (pembelajaran jarak jauh), dan semua stakeholder harus menyiapkan semua perangkat Pembelajaran Jarak Jauh (PJJ) sebagaimana sebagaimana tercantum pada Surat Edaran (SE) Mendikbud Nomor 15 tahun 2020 (Kemendikbud, 2020b) tentang "Pedoman Penyelenggaraan Belajar Dari Rumah Dalam Masa Darurat Penyebaran Covid-19”. .11]

Pembelajaran daring membutuhkan perangkat keras dan perangkat lunak yang cukup baik sehingga dapat terlaksana dengan baik. Salah satu Perangkat lunak yang dibutuhkan adalah Learning Management system (LMS) [2]. LMS sangat banyak tersedia saat ini, ada yang berbayar dan ada yang free. LMS yang dikembangkan seperti moodle banyak digunakan oleh perguruan tinggi, selain karena fitur yang tersedia sangat lengkap, juga karena mudah dalam pengembangannya. LMS berbasis moodle juga digunakan di Universitas Negeri Makassar yang dikembangkan menjadi System and Application Management Open Knowledge (SYAM OK).
SYAM OK UNM memiliki banyak keunggulan dibanding LMS yang sebelumnya digunakan yakni pembelajaran dapat dilaksanakan secara synchronous dan Asynchronous. Fitur yang tersedia terintegrasi dalam SYAM OK sehingga mudah bagi dosen dalam pengelolaan kelas dalam pembelajaran.

Mahasiswa juga mudah dalam mengaksesnya karena LMS berbasis website. Pembelajaran di UNM menjadi satu kesatuan dalam SYAM OK dan terintegrasi dengan sistem informasi akademik, dan melalui SYAM OK pembelajaran dapat dimonitoring dan dapat dilakukan evaluasi sesuai dengan aktivitas yang dilakukan dosen dan mahasiswa. Oleh karena itu pembelajaran di UNM tidak lagi berbeda antar jurusan atau berbeda masing-masing dosen yang sebelumnya ada yang menggunakan platform google classroom, kelase, schoologi, Edmodo, dll sehingga sulit untuk dilakukan monitoring pembelajaran. Selain itu Terdapat beberapa acuan yang digunakan sebagai bahan pertimbangan untuk menentukan baik buruknya kualitas sebuah website. Sebagai bahan pertimbangan yaitu: kecepatan akses, isi mudah dibaca, dan tata letak atau desain yang konsisten. [3]

Mengingat saat ini proses pembelajaran dilakukan di tengah pandemi covid-19 maka hampir keseluruhan proses pembelajaran dilakukan secara daring, sehingga kemandirian mahasiswa dalam belajar merupakan modal utama yang harus dimiliki oleh mahasiswa 
untuk mencapai hasil belajar yang baik [4]. Sebagai upaya meningkatkan kemandirian belajar mahasiswa maka perlu LMS yang berkualitas dalam mendukung pembelajaran. Hadirnya SYAM OK dan diterapkan secara keseluruhan jurusan di UNM tentu saja perlu memperhatikan performance tingkat stress dalam mengaksesnya. Oleh karena itu dalam penelitian ini dilakukan pengujian performansi terhadap SYAM OK UNM.

\section{METODE PENELITIAN}

Penelitian ini merupakan penelitian survey dengan dengan menggunakan Teknik observasi pada website. Objek observasi penelitian ini adalah LMS SYAM OK Universitas Negeri Makassar dengan menggunakan Pingdom tools [3] dan GTMATRIX untuk melihat dan membandingkan performansi LMS SYAM OK. Pingdom Tools merupakan sebuah alat ukur kecepatan website dapat di akses, nilai dari sebuah website, dan berapa ukuran dari sebuah website tersebut. Beberapa kelebihannya di kategorikan sebagai berikut:

1. Performance Grade: melihat nilai kecepatan performa halaman web, dari akses DNS, browser cache, combine external css dan lain-lain.

2. Load Time: melihat detail kecepatan akses ketika membuka halaman web, dari gambar bahkan sampai seberapa cepat script tersebut dapat di akses.

3. Page Size: melihat detail analisa halaman web.

4. Requests: melihat detail akses dari beberapa hari lalu [3]

GTMetrix adalah layanan yang bisa dipakai untuk mengecek performa sebuah website. GTMetrix sebenarnya kombinasi dari tool Yahoo Slow! dan Google Pagespeed berbasis web. GTmetrix akan mengukur kecepatan website dan menampilkan hasilnya secara detail. Poin akhir dari GTMetrix adalah A sampai F. A artinya sangat bagus $F$ artinya sangat buruk. Untuk mendapatkan poin $A$, anda harus mempunyai skor diatas 90 [3]

Pengujian performansi LMS SYAM OK menggunakan tiga buah metode pengujian yaitu:

1. pengujian performansi dan kecepatan

2. pengujian Load Test

3. pengujian stress

Metode uji performansi dan kecepatan dan stress dilakukan melalui GTMetrix dan metode uji Load Test yakni WebPageTest. GTMetrix menguji seberapa cepat dan efisiennya sebuah website tersebut berjalan saat digunakan [5]. LoadStorm adalah pengujian stress test, dimana website tersebut dicek response timenya saat request diterima, mengecek juga kecepatan transfer data, juga mengecek jumlah error yang terjadi saat menerima data [5].

\section{HASIL PENELITIAN}

1. Hasil Pengujian Performansi

a. Menggunakan Pingdom Tools

Hasil pengujian performansi LMS SYAM OK menggunakan Pingdom tools ditunjukkan pada gambar berikut ini:

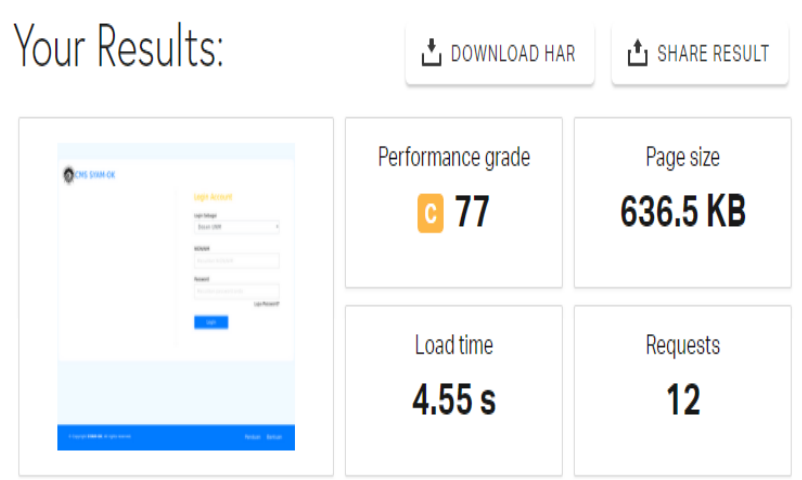

Gambar 1 Hasil Pengukuran Pingdom

Dari hasil pengukuran seperti gambar di atas didapatkan performance grade 77 atau grade $\mathrm{C}$ yaitu cukup baik. Hasil sangat baik apabila hasil pengukuran pada grade $\mathrm{A}$ dan baik pada grade $\mathrm{B}$. pengukuran page size 636,5 KB dan Load time 4,55 s dengan hasil request 12 . Berikut ini hal-hal yang perlu diperbaiki:

Improve page performance

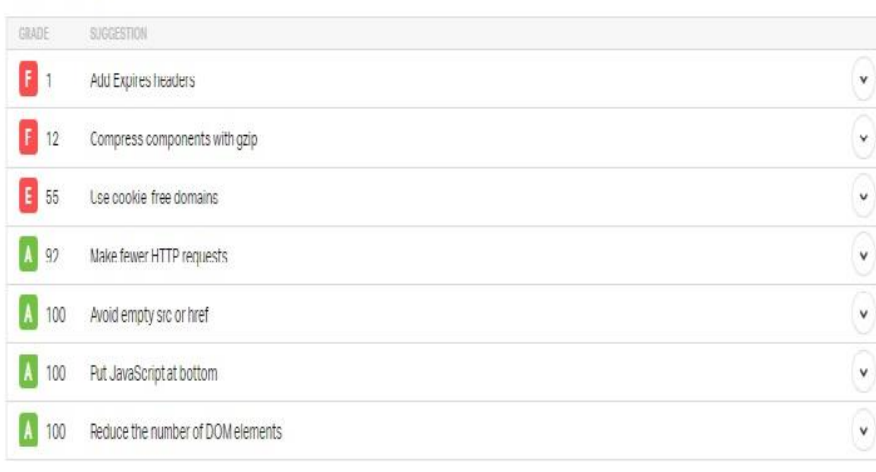

Gambar 2 Improve Page Performance

Hasil diatas menunjukkan hal apa saja yang direkomendasikan dan hal yang masih kurang. Hal yang direkomendasikan dengan katergori sangat baik adalah make fewer HTTP request, Avoid empty src or href, Put Javascript bottom, dan reduce the number of DOM elements. Sedangkan hal yang masih perlu diperbaiki seperti compress components with gzip, add expires headers dan use cookies free domain.

b. Menggunakan GTMetrix

Hasil pengujian performansi website SYAM OK UNM menggunakan GTMetrix ditunjukkan pada gambar berikut: 


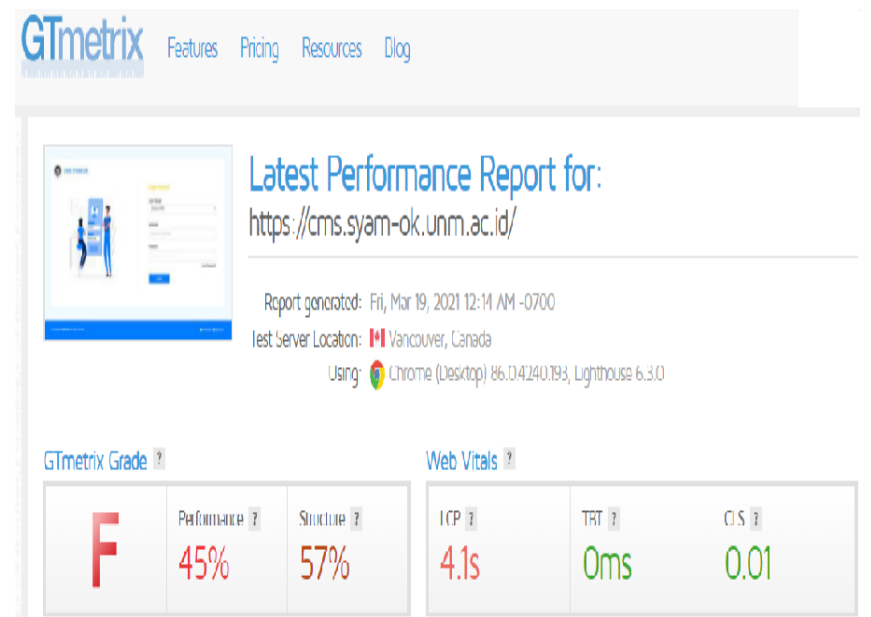

\section{Gambar 3 Hasil Pengujian CMS dengan GTMetrix.}

Berdasarkan hasil pengujian website CMS SYAM OK UNM menggunakan GTMetrix menunjukkan page speed score pada kategori $\mathrm{F}$ dengan performance $45 \%$. Dari hasil tersebut menandakan bahwa performa website masih kurang baik, dengan kategori sangat baik apabila gradenya A. Untuk mendapatkan grade A nilai yang harus diperoleh adalah 90

Rincian data performance ditunjukkan pada gambar berikut:

\section{Fettornance Metitics}

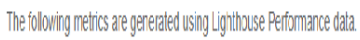
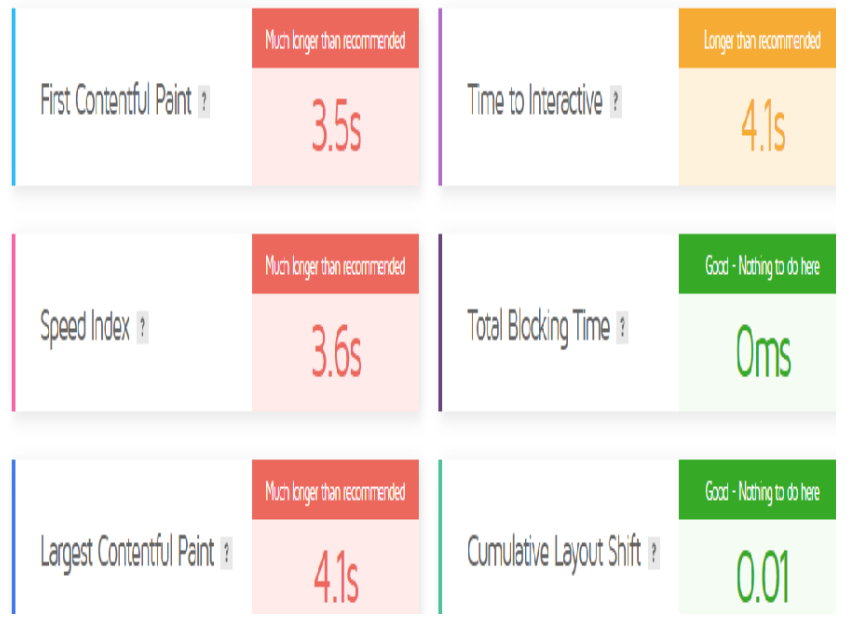

Gambar di atas menunjukkan first contenful pain lebih lambat dari yang direkomendasikan, speed index lebih lambat dari yang direkomendasikan, Largest Contentful paint lebih lambat dari yang direkomendasikan, dan time to interactive cukup lambat dari yang direkomendasikan, sedangkan total blocking time berkategori baik dari yang direkomendasikan, dan cumulative layour shift berkategori baik dari yang direkomendasikan.

\section{Pengujian Load}

Pengujian load test dilakukan melalui webpagetest.org. hasil pengujian ditunjukkan pada gambar berikut ini:
Web Page Performance Test for
https:I/loms.syam-ok.unm.ac.idl|

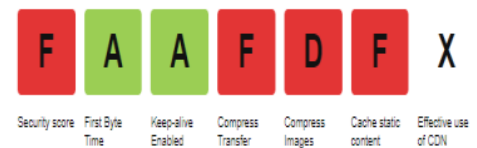

Gambar 4 Hasil pengukuran load Testing

Pada pengujian load test terhadap website SYAM OK UNM diperoleh data security score pada grade F, Compress time pada grade F, Cache Static Test pada kategori F, sedangkan First Byte time dan Keep alive enable pada grade A, dan compress Image pada grade $\mathrm{D}$.

Hasil pengukuran load setiap komponen website SYAM OK UNM ditunjukkan pada gambar berikut:

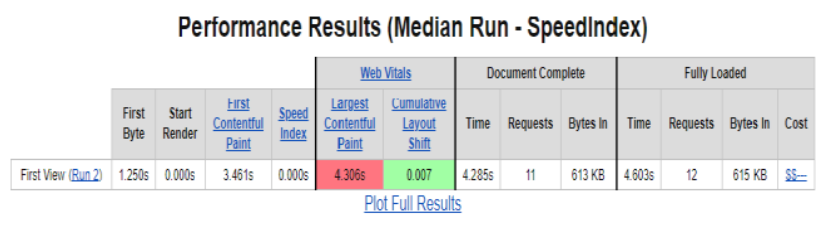

Gambar 5 Pengukuran Komponen load test

Pengukuran komponen load test ditunjukkan pada gambar 5 yaitu nilai pada load time dan load request cukup baik yakni bernilai 4 , $18 \mathrm{~s}$ dengan request load bernilai 12.

\section{Pengujian Stress}

Pengujian stress website dilakukan dengan menggunakan Loadstorm.com. Hasil pengujian ditunjukkan pada tabel berikut ini:

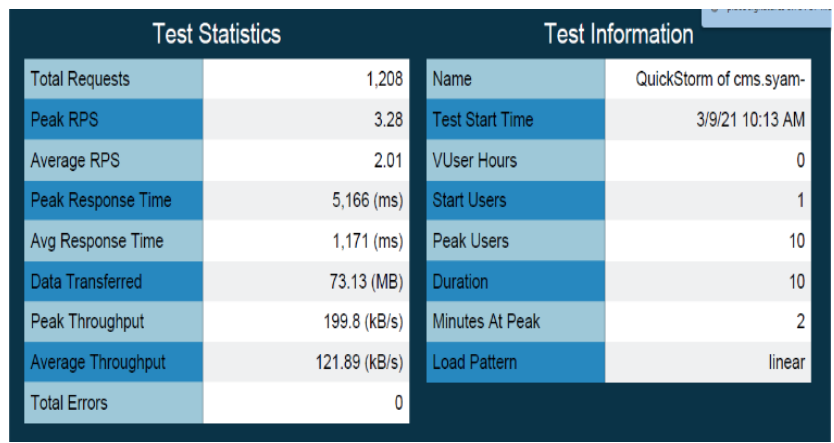

TABEL I

HASIL PENGUKURAN LOAD STORM PADA WEBSITE SYAM OK UNM

Pada tabel pengukuran stress website SYAM OK UNM menggunakan Load storm diperoleh data total request 1206. Jadi jumlah request website cukup tinggi. Waktu respon yang dibutuhkan oleh website menanggapi respon user adalah 1,171 s yang artinya masih agak lambat waktu responnya untuk menanggapi user. Kemampuan data transfer adalah 73,13 yang menandakan bahwa website SYAM OK memiliki tingkat stress cukup tinggi dalam menanggapi user. 
Jurnal MediaTIK : Jurnal Media Pendidikan Teknik Informatika dan Komputer

Vol.4 No.1 (Januari 2021)

\section{IV.KESIMPULAN}

Ada banyak cara dalam pengujian website dan banyak pula indicator yang dapat diukur. Indicator-indikator tersebut antara lain adalah interface, performansi, kecepatan, load test, stress, vulnerability seperti SQL injection, dll. Namun dalam penelitian ini hanya dilakukan pengujian performansi dan kecepatan, load test dan stress. Ketiga indikator ini cukup memberikan gambaran tentang performansi suatu website dalam mempertahakan maupun menjadi bahan rekomendasi dalam peningkatan dan pengembangan website.

\section{DAFTAR PUSTAKA}

[1] T. Pedoman, P. Belajar, R. D. Masa, and D. Penyebaran, "Surat Edaran Sekretaris Jenderal Kemendikbud,” 2020.

[2] T. H. Setiawan and Aden, "Efektifitas Penerapan Blended Learning Dalam Upaya Meningkatkan Kemampuan Akademik Mahasiswa Melalui Jejaring Schoology Di Masa Pandemi Covid19," J. Pembelajaran Mat. Inov., vol. 3, no. 5, pp. 493-506, 2020.

[3] Suliman, "Analisis Performa Website Universitas Teuku Umar Dan Universitas Samudera Menggunakan Pingdom Tools Dan Gtmetrix," Simkom, vol. 5, no. 1, pp. 24-32, 2020.

[4] Y. Yuliati and D. S. Saputra, "Membangun Kemandirian Belajar Mahasiswa Melalui Blended Learning Di Masa Pandemi Covid19," J. Elem. Edukasia, vol. 3, no. 1, pp. 142-149, 2020.

[5] F. Wiharjo, G. Irfon.E.S2, and R. Maulana, "Software Testing Pengujian Performansi dan Tingkat Stress Pada Website Ekspedisi JNE dan TIKI," pp. 1-5, 2017. 